\title{
Performing biospheric futures with younger generations: a case in the MAB Reserve of La Sepultura, Mexico
}

\author{
Maria Heras ${ }^{1}$, J. David Tabara $^{1}$ and Amayrani Meza ${ }^{2}$
}

\begin{abstract}
Providing opportunities for younger generations to voice out their views in the building of our common futures within the limits, opportunities, and dynamics of the biosphere is a central component in sustainability learning. To this aim, a novel methodological approach using participatory theater was implemented to explore future scenarios with young people in the Man and Biosphere Reserve of La Sepultura, Mexico. Three workshops were carried out as part of a broader environmental education process, aimed at enhancing critical awareness and ownership of participants' own futures. Through the reflective enactment of scenarios linked to personal actions and resources, alternative ways to think through the interconnections and the affective bonds between participants and their natural heritage were collectively represented and explored. Our process helped not only to identify different plausible futures and potential barriers to them, but also to realize positive roles that young people could play to overcome such barriers and engage with their desired futures.
\end{abstract}

Key Words: applied theater; art-science interface; learning for sustainability; participatory scenarios; performative methods; visioning

\section{INTRODUCTION}

Recognizing young people as key actors in the construction of sustainability narratives entails the need to create opportunities by which their ideals and ambitions can be expressed and heard. They require learning spaces where they can speak out, and be properly recognized, so they can articulate and materialize their hopes and desires about the future (Hicks 1996, Krasny et al. 2009). To a large extent, the current social-ecological crisis is a crisis of meaning, with perceptions and values largely still based on false dualisms between the mind and the body, the present and the future, and "me" and "the others." Our present situation unveils the limitations of dominant worldviews, mostly uncoupled from biophysical changes and unable to react accordingly to them (Tàbara and Chabay 2013). More "know-why," i.e., an improved understanding of the complex dynamics of motives and motivation, is needed to consciously envision and engage people in the building of sustainable futures (Orr 1992).

To mobilize people in sustainability we need transformative visions that can be collectively coconstructed and linked to action. As noted by Meadows et al. (1992), vision without action is useless, but action without vision "does not know where to go or why to go there." Visioning plays a crucial role in building the future and when merged with critical thinking, it has the potential to connect with people's motives and aspirations, and be conducive to informed purposive action (Tilbury and Wortman 2004, Wayman 2009). In this respect, the arts have a promising potential in the development of visions about the future while offering intuitive, experiential, and less inhibited ways to explore and represent systems dynamics and people's positions in these dynamics from different perspectives (Curtis 2009, Curtis et al. 2012, Wiek and Iwaniec 2014, Scheffer et al. 2015). Furthermore, the arts can help strengthen emotional bonds between places and people, which lie at the base of personal motives for caring and acting (Inwood 2008, Kagan 2008, Selman et al., 2010). Arts' appeal to open our senses to diverse ways of understanding the world beyond rationality is especially relevant when working in educational programs among young people, because of the capacity of the arts to foster different approaches to learning in highly explorative and motivating ways (McNaughton 2004, Flowers et al. 2015, Scheffer et al. 2015).
Although the arts provide endless possibilities for methodological innovation, Man and Biosphere (MAB) Reserves are especially fit for purpose to explore interactions within social-ecological systems and support transformative learning. These UNESCO sites were originally set up to reconcile biodiversity conservation and the maintenance of cultural heritage with the sustainable use of natural resources (UNESCO 2014). However, MAB Reserves have moved their program implementation from a science-driven agenda to a social learning one, which emphasizes local participation and learning processes (Reed and Massie 2013). In this fashion, they constitute, highly relevant laboratories for sustainability learning and experimentation (Schultz and Lundhom 2010).

Building on the notion of performative methods for sustainability (Heras and Tàbara 2014), in this paper we further explore the learning potential and limitations of integrating applied theater (AT) in the development of futures thinking with young people. In particular, the objective of our research was twofold: (1) to identify the main methodological features in which the design of performative future exercises can be implemented successfully in educational programs and (2) to assess to which extent these novel methodological designs can contribute effectively to sustainability learning in contexts such as the MAB Reserves.

\section{LEARNING FROM THE FUTURE: ON VISIONS, SCENARIOS, AND PLAYS \\ The future can't be predicted, but it can be envisioned and brought lovingly into being. (Meadows 2001)}

Visioning the future, navigating sustainability

Sustainability transformations are in their broadest sense processes of social learning (Pahl-Wostl et al. 2007, Barth and Michelsen 2013, Tàbara 2013). Acknowledging the cultural and political dimension of sustainability implies cultural transformations affecting our ways of knowing, learning, valuing, and acting together (Kagan 2008). Visioning, i.e., the articulation of visions about preferable futures, is a crucial element in designing such transformations, because visions are essential to guide and motivate action (Meadows et al. 1992). By connecting with people's aspirations and motives, imagining the future can 
offer direction and boost social energy, providing impetus for transforming the present (Tilbury and Wortman 2004). Creating a sense of ownership about the future ("the future is also mine") is a decisive component in the articulation of collective action based on personal engagement and purpose.

In this regard, the need to build capacities and competences to envision and contribute to futures thinking has been widely acknowledged (Hicks 1996, Meadows 2001, Robinson 2003, Miller 2007). Futures thinking requires social imagination, critical understanding, reflexive dialogue, and collaborative action (Miller 2006, Wayman 2009, Lehtonen 2012). Entering into the exploration of the future in the most unconstrained way possible can help extend the range of possibilities about what can be done in the present and our different roles to play, hence helping to develop a sense of agency (Inayatullah 2002, as cited in Wayman 2009). Moreover, futures thinking can provide navigational tools to inform decision making both at collective and individual levels (Miller 2006). By participating in the creation of futures, people can gain diverse skills and competences, which can be identified as (1) intellectual, e.g., imagining and reflecting about the future; (2) social, e.g., collaborative work; (3) normative, e.g., uncovering values, beliefs, and assumptions underlying visions and choices; and (4) affective, e.g., managing emotional dilemmas (Tilbury and Wortman 2004, Head 2011, Wiek and Iwaniec 2014).

\section{Performing futures, learning opportunities}

The competence perspective emphasized in futures thinking is especially relevant for educational approaches and programs aimed at supporting sustainability learning. A growing awareness of the complex, dynamic, and normative character of sustainability has broadened the scope of educational approaches from the cognitive dimension to include also the affective, normative, and competence aspects of learning (De Haan 2006, Frisk and Larson 2011, Wiek et al. 2011). Such holistic approaches often emphasize the relevance of experiential learning when approaching highly dynamic systems and the need to combine different ways of learning, knowing, and valuing reality (Sterling 2003, Dieleman and Huising 2006, Sipos et al. 2008). This perspective is particularly important when dealing with the many uncertainties about the future. Experiential learning involves direct, active, personal, hands-on exploration and testing combined with reflection and the integration of feedback to develop not only more but also mostly different kinds of knowledge, skills, and attitudes (Kolb 1984, UNESCO 2007). Feeling and sensing (the Aha! emotion), not only understanding sustainability as an abstract and distant concept, become crucial in sense-making and in engaging oneself in the sustainability journey.

AT can provide significant opportunities for experiential learning in sustainability education, both in formal and informal contexts (Nicholson 2005). It refers to a wide range of dramaturgic activities, primarily carried out outside ordinary theater settings, specifically intended to benefit individuals, communities, and societies who perform them (Nicholson 2005). AT has a long tradition in learning and educative contexts, through approaches such as theater in education (see, for instance, Waters et al. 2012) and educational drama (see Schonmann 2011 for an overview of the concept). Through theatrical exercises and plays, participants can share, recreate, and reflect upon personal stories, stimulating dialogue and potentially generating new collective meanings (Van Erven 2000, Sloman 2011, Greenwood 2011). The rehearsal for action involved in improvisations can also encourage participants to engage in immediate action and active experimentation (Boal 1992). Such a rehearsal supports the practice of social and decision-making skills (Waters et al. 2012), often with a potential empowering effect on the participants, by identifying and performing issues and decisions that are of their own concern (Boal 2009, Sloman 2011). In this sense, AT within educational processes can activate resources for social and political action (Van Erven 2000, Conrad 2004, Nicholson 2005) and stimulate a sense of ownership of the future.

Following previous experiences at the intersections of futures thinking and AT (Head 2010, 2011, 2012, Lethonen 2012), we now share an original experience aimed at exploring the potential of futures learning through AT in the specific context of a MAB Reserve.

\section{PERFORMING BIOSPHERIC FUTURES IN THE MAB RESERVE OF LA SEPULTURA}

\section{Implementation context}

La Sepultura is a UNESCO MAB Reserve located at the west of Chiapas, Mexico, covering an area of 167.309 ha of high biodiversity and endemic species (Fig. 1). La Sepultura is mainly composed by a big buffer zone where farming and agriculture are allowed under some restrictions and a small core zone (less than $10 \%$ ) where human activities are totally prohibited (Speelmann et al. 2014).

Fig. 1. Location of La Sepultura Man and Biosphere Reserve, Chiapas, Mexico. Source: Google.maps.

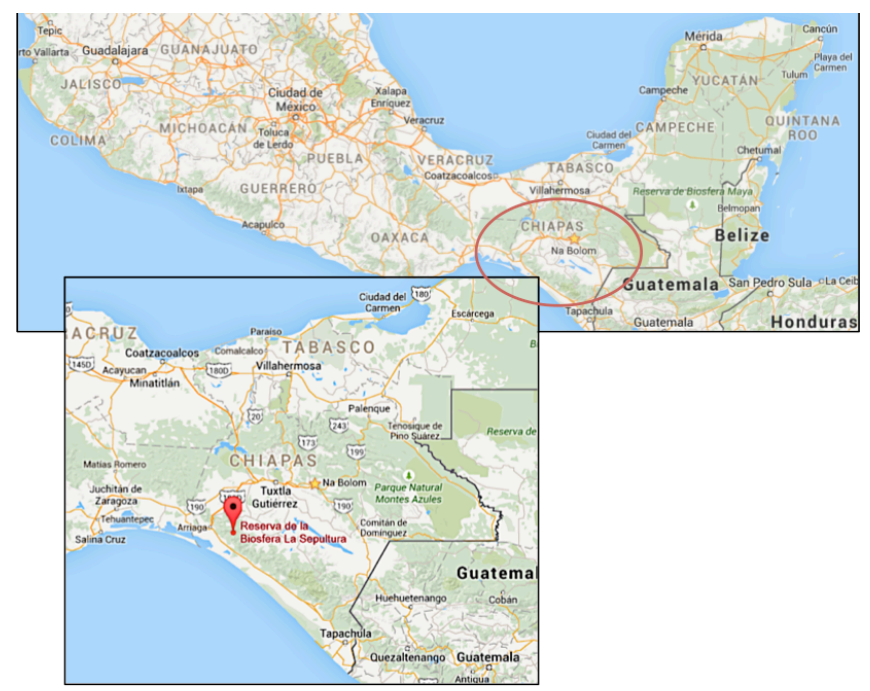

Our research took place in Los Angeles, a farming community of 1000 inhabitants, located within La Sepultura since 1960 (Sanfiorenzo-Barnhard et al. 2009). From the 1970s onwards, the expansion of commercial corn production in the area resulted in deforestation and severe erosion (Trujillo 2010). The establishment of the MAB Reserve in 1995 changed that trend, and current land-use types include staple food production for home consumption, pasture-based livestock production, and 
cash crops, like organic shade coffee and palm oil plantations (Speelmann et al. 2014). However, the lack of enough soil cover in many farmlands and the implementation of uncontrolled and inappropriate farming programs and practices are still causing further erosion, landslides, and forest loss (García-Barrios et al. 2006, Trujillo 2010).

Within this social-ecological context, a participatory and innovative environmental education project was developed between summer 2014 and winter 2015 addressed to young people. Under the title "What motivates young people from La Sepultura to preserve or degrade their environment?" the project designed and assessed sustainability education tools (Meza 2015). A participatory process was generated with 3 groups of young students from 13 to 18 years old to explore their actions, motivations, and perceptions about their relationship to the MAB Reserve. Among the various tools used, three table games were played by participants, based on resource management strategies with varying degrees of difficulty and social interaction (individual, in pairs, and in teams). During the games, three types of behaviors combined with strategies of dominance and equity were identified: conservation, intensification, and diversification. Individual interviews using Q method were also conducted at the end of the process to support the exploration of participants' perspectives.

In combination to these, AT was used during three consecutive workshops held between September and October 2014. The different resource-use strategies emerging from the games were then connected with different community future alternatives for the MAB Reserve. By theatrically exploring participants' visions of La Sepultura in 2030 and bringing them to the present, the intervention expected to provide links between participants' perceived challenges, desires, and motivations, so as to support critical awareness and engagement in collective action.

\section{Methodological approach and research process}

Our methodological approach integrated several theatrical techniques from Brazilian dramaturge Augusto Boal into an educational drama approach, to facilitate a learner-centered process. Table 1 summarizes the various techniques applied.

\section{The theatrical sessions}

The theatrical workshops were composed of 3 sessions of 3 hours each, developed in 3 consecutive days. Activities were scheduled at school time to ensure participants' availability. Consequently, participation was extended to the whole school grade $(n=90)$. Each workshop involved between 24 and 30 participants from 3 different age groups between 12 and 18 years old, organized in group 1 (hereinafter G1, 15-17 years old), group 2 (G2, 14-15 years old), and group 3 (G3, 12-14 years old). Two facilitators guided the process: one environmental educator involved in the community educational program, who had previously worked with the participants; and an environmental researcher with background in participatory theater. Also, a young man from the community voluntarily provided facilitation support in some workshop sessions.

The sessions were designed with a common structure, consisting of (1) a warm-up, as a first block of theatrical games and exercises introducing participants to the theatrical language; (2) the main performative activity, involving collective creation in subgroups and performance before the whole group; and (3) group debriefing, in which participants and facilitators shared appreciations and reflections about the whole process. This sequence was designed so as to facilitate different forms of experiential learning (Kolb 1984): (1) experiencing or apprehension, based on felt experience and active experimentation while performing; and (2) understanding or comprehension, based on later debriefing or reflection on action, thus connecting experiential insights to wider systems and critical thinking. An overview of the workshops' structure is provided in Appendix 1.

Table 1. Main techniques of applied theater used in our performative approach. Based on Boal's theater techniques (Boal 2001).

Theatrical games:

Exercises and aesthetic games that activate different senses and body expressiveness, provide experiences of abstract concepts and help create self and group awareness.

Image theater:

Creation of body sculptures to compose theatrical images through which participants can explore symbolic language and mental representations about the topics explored. Image theater works with collective images that connect individual with social visions.

Forum theater:

Creation of a theatrical play based on participants' experiences in which spectators can enter into scene and change the course of events in search of alternative developments. Through a forum theater piece participants can (1) identify a conflictive situation, its actors, relationships, and interests; (2) analyze the situation and recognize different possibilities of action; (3) activate themselves and experiment with such possibilities by performing them in scene; and (4) collectively reflect on and discuss the outcomes of the rehearsed action.

Session 1: Picturing our community

The first session was focused on creating a comfortable and creative atmosphere, and generating a shared picture of the community to help ground discussions in the next days. Through the session's performative activity, participants explored and reflected about their mental representations of their community, their main actors, and the social-ecological interactions involved. Two groups were created, and participants were asked to react to several guiding questions and create a collective still image of the community of Los Angeles (subgroup 1) and of the youth in the community (subgroup 2). Under the motto "Three, two, one... Action!" these images were then "activated" and further explored by adding sound, dialogue, and movement. Each subgroup was invited to react to the images created by the others, so that participants could change or add elements in scene to create a final integrated and agreed-upon image. During the debriefing, participants shared reflections and feelings about these images, on who they are as a community, and what their role is as young people (see Appendix 1).

\section{Session 2: Visioning futures}

During the second session, participants began to explore scenarios and visions of the future through the theatrical creation of alternative future scenes for the MAB Reserve. The group was divided into four subgroups. Three of them represented plausible futures, each based on a land-use strategy previously identified in 
the games: conservation scenario (e1), diversified scenario (e2), and intensive scenario (e3). The last group performed their desired vision of the future without any constraints (e4). Exceptionally, in G1 we only developed three scenarios (e1-e3) because of time constraints.

Prior to creation, facilitators introduced to each group a land-use strategy and provided them with a set of question cards addressing six critical dimensions as main input for discussion (see Table 2). With these inputs, each subgroup built a theatrical image using the resources at hand, i.e., their bodies, the classroom, and outdoor materials. The images, different pictures from alternative futures, were then performed to the whole group in an improvised scenario, and the different characters were activated. This way, small dialogues and improvised scenes could further unfold the symbolic language of their images.

Table 2. Evaluation of workshop effectiveness perceived by participants.

\begin{tabular}{|c|c|c|c|}
\hline Perceived workshop effectiveness ${ }^{\dagger}$ & $\begin{array}{c}\mathrm{G} 1 \\
(\mathrm{n}=14)\end{array}$ & $\begin{array}{c}\mathrm{G} 2 \\
(\mathrm{n}=27)\end{array}$ & $\begin{array}{c}\text { G3 } \\
(n=26)\end{array}$ \\
\hline Sense of group & 97.1 & 86.7 & 92.3 \\
\hline Expressive skills & 92.9 & 85.9 & 85.4 \\
\hline $\begin{array}{l}\text { Reflections about their community and } \\
\text { relevant actors }\end{array}$ & 88.6 & 82.2 & 83.8 \\
\hline Visions of different community futures & 85.7 & 82.2 & 88.5 \\
\hline $\begin{array}{l}\text { Positive and negative aspects in their } \\
\text { futures }\end{array}$ & 87.1 & 81.5 & 86.9 \\
\hline $\begin{array}{l}\text { Social-ecological challenges in the Man } \\
\text { and Biosphere Reserve }\end{array}$ & 88.6 & 84.4 & 93.1 \\
\hline Exploration of proposals of action & 81.4 & 83.0 & 86.2 \\
\hline $\begin{array}{l}\text { Sharing of personal experiences, views, } \\
\text { and attitudes }\end{array}$ & 90.0 & 79.3 & 83.1 \\
\hline
\end{tabular}

A guided debriefing was facilitated so both the audience and the actors could react to each image. In this way, observations about the different elements and the various relationships performed were collectively and openly shared, and participants could express their felt experiences and perceived social-ecological connections within the MAB Reserve. For each future, a list of positive and negative aspects was identified and discussed. Comparisons among futures were made to identify those preferable futures as well as the main components of them.

\section{Session 3: Rehearsing present transformations}

During the third session, and inspired by "back-casting techniques" (Robinson 2003), we applied forum theater (Boal 2002) to explore different actions supporting change toward the desirable futures, therefore constituting a sort of dramatized back-casting. The various futures were brought into the present with the help of different aspects identified in the performed scenarios the previous day. Participants were first asked to individually identify one or two situations in their daily life that they would like to change, related to any of the negative aspects previously identified. Then, in subgroups of five or six people, they were asked to share these stories and create a theatrical scene based on them. While creating these scenes, participants had to explore and recreate their main characters, their relationships, conflicts, and possible endings.

Following the technique of forum theater, each subgroup presented their scenes, now turned into scenarios linked to action, to the audience, who was then encouraged to engage in a dialogue about the sustainability of the MAB Reserve and the different opportunities for transformation. Participants were invited to jump into these scenes and further elaborate on the actions proposed to test their validity and robustness through the theatrical rehearsal. This way, different action proposals focused on the youth emerged from each scene, facilitating different reflections on the performed actions.

\section{Data collection and analysis}

Research data were gathered both through participant observation during the performative workshop and various evaluation tools applied at different moments. Research data consisted mostly of (1) researchers' and facilitators' notes and audiovisual recordings of theatrical improvisations and group reflections, including outcomes of group discussions; and (2) participants' individual reflections and perceptions, gathered through the following evaluation tools:

- A qualitative evaluation, based on a final open questionnaire $(\mathrm{n}=80)$ and reflection cards after the first two sessions $(\mathrm{n}=$ 111).

- A 5-point Likert scale $(n=90)$, handed in before and after the workshop to track changes in participants' perceptions and attitudes.

- A feedback questionnaire $(n=56)$, handed in four months later to assess the workshop's effectiveness (see Table A2.1 in Appendix 2 for more details on these evaluation tools).

Two main analysis strategies were used: a qualitative content analysis of researchers' notes and the open evaluation, and an inferential and descriptive statistical analysis of pre- and postworkshop questionnaires. Table 3 further describes the analysis strategies.

Table 3. Analysis strategies.

Qualitative content analysis:

A qualitative content analysis of theatrical improvisations and group debriefings, supported by the audiovisual recordings, was carried out to track emerging thematic contents and discussion insights. Furthermore, the analysis of researchers' notes also focused on group processes and dynamics and on participants' reactions to the methods that had been proposed. Materials from the qualitative evaluation were then analyzed using Atlas.ti 6.2 (Muñoz and Sahagún-Padilla 2011) to explore participants' learning experiences. Participants' answers were analyzed creating 120 emergent codes, which were then compared and clustered into three broader learning categories:

(i) Awareness, knowledge, and understanding

(ii) Attitudes and values

(iii) Social skills and competences

Each group was firstly analyzed separately, allowing for comparisons among the three groups.

Statistical analysis:

Regarding the pre- and postworkshop questionnaires, a Wilcoxon Test for nonparametrical two related samples was applied together with descriptive statistics, using the software Stata 13 (Sprent and Smeeton 2001). Of the 90 questionnaires, 73 were selected for analysis, corresponding to those participants answering both pre- and postworkshop questionnaires. The return questionnaire was analyzed using descriptive statistics. 
Fig. 2. Summary of the different scenarios performed. Photos: two moments from the workshop (conservation scenario and diversified scenario).

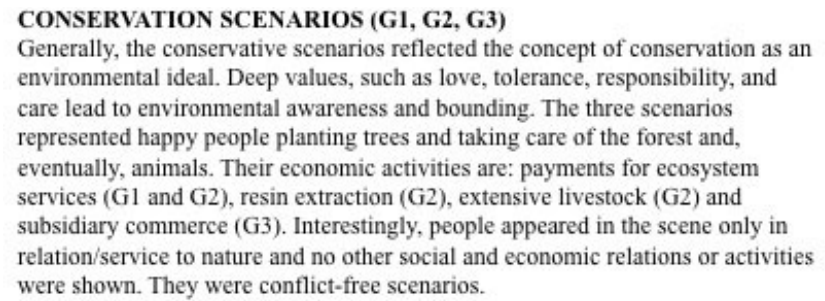
environmental ideal. Deep values, such as love, tolerance, responsibility, and care lead to environmental awareness and bounding. The three scenarios represented happy people planting trees and taking care of the forest and, eventually, animals. Their economic activities are: payments for ecosystem services (G1 and G2), resin extraction (G2), extensive livestock (G2) and subsidiary commerce (G3). Interestingly, people appeared in the scene only in relation/service to nature and no other social and economic relations or activities were shown. They were conflict-free scenarios.

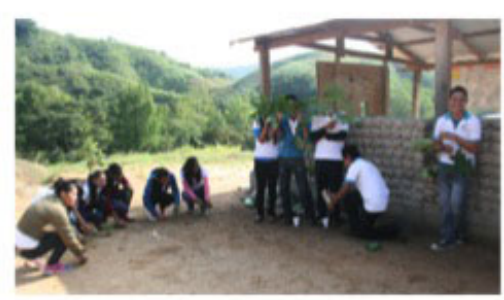

\section{DIVERSIFIED SCENARIOS (G1, G2, G3)}

Diversified scenarios presented a wide range of economic activities: agriculture, livestock, fishing, forestry and commerce. Nevertheless, while G2 and G3 characterised these activities as extensive, respecting nature cycles and sustaining an ecological balance, G1

characterised them as deeply resource-intensive and associated to high social conflict (e.g. violence, mistrust, migration). In that case, diversification was a strategy following values of maximum profit, competitiveness and human supremacy, in contrast to the other groups, which were driven by respect and care towards nature.

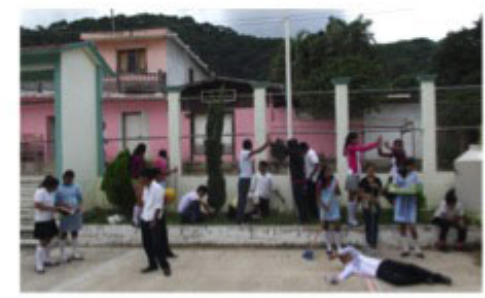

$$
\begin{aligned}
& \text { INTENSIVE SCENARIOS (G1, G2, G3) } \\
& \text { Intensive scenarios represent a diversity of productive activities (like in e2), } \\
& \text { but pushed to the extreme. Consequently, different socioecological problems } \\
& \text { arise, such as forest loss, land, water and air pollution and degradation, } \\
& \text { increasing temperatures, social inequality, violence or mistrust. Interestingly, in } \\
& \text { G2 technocrats (e.g. researchers, agricultural engineers, veterinarians, } \\
& \text { government members) rule the scenario; and G1 also highlights government } \\
& \text { members as providers of agrochemical inputs. Environmental detachment, } \\
& \text { egoism, irresponsibility, aggressive competition and a lack of concern about } \\
& \text { future generations are people's main motives behind these scenarios. }
\end{aligned}
$$

\section{DESIRED SCENARIOS (G2, G3)}

Desired scenarios showed particularities for each group. In G2, the desired scenario was characterised by urban development respectful with the socio-ecosystem. The image represented more services and technology in the community (e.g. better access to electricity and internet, more schools and health centres), the maintenance of extensive livestock farming and more presence of politicians.

G3 showed a unified community where coordination, mutual support and communication helped people keeping clean their village, river and surroundings, recovering forest areas and reducing land pollution. In this future, the youth was leading the social transformations. Both groups expressed the desire for more employment and a preference for extensive livestock farming as economic activity.

\section{RESULTS}

Two kinds of results were identified from our experience: (1) those related to the specific material outputs of the performative future scenarios, i.e., different plausible and desired futures and action proposals related to them; and (2) those related to participants' personal learning experiences, i.e., process outcomes. Because of the methodological orientation of our research, our analysis will mostly focus on procedural aspects of the use of theater in developing futures in La Sepultura MAB Reserve.

\section{Scenario outputs: participants' futures and proposals for action}

\section{Exploring futures: fears and desires}

During the second session, each group performed three plausible futures or exploratory scenarios according to different land-use trends and one desired or normative future, which constituted their vision of the future (see Fig. 2). Through these futures, participants could imagine, embody, and discuss different perspectives about the future, identify positive and negative aspects within them, and compare them with their desired vision.

The scenarios revealed future imaginary and present concerns, in which pieces of information and facts about the MAB Reserve were combined with normative aspects and broader views. After each representation, both desirable and undesirable aspects in their enacted futures were identified. Desirable aspects emphasized social transformations and often related to enhanced mutual support, communication, collective action, and communion with nature. The wish for more services and economic activities in the community reflected in their performed scenes made visible some tensions and narrative inconsistencies. For instance, on the one hand, the ideal of an almost pristine future of total conservation, with very little economic activity or human presence in the MAB Reserve, conflicted with the desire for more economic and urban development in their community. On the other hand, although participants acknowledged the negative social-ecological impacts of some of the agrarian practices currently being practiced in the MAB Reserve, there was a general difficulty in thinking of alternative ways of doing things.

Back from the future: current concerns and proposals for change During the third session, future dimensions were brought back to the present by encouraging improvisations of everyday situations related to social-ecological challenges and by the rehearsal of action proposals through forum theater and consecutive discussions. Participants' scenes showed their perceived main problems concerning sustainability, which included (1) environmental pollution, waste management, and their impacts on people; (2) the loss of forests because of commercial logging and agrarian activities; and (3) social conflicts, partly rising from high competitive attitudes within the productive system, people's indifference toward some social problems, and politicians' abuse of power.

These represented situations constituted a starting point from which different "futures-in-the-present" could be activated so that young people could reflect on the possible actions at hand. 
Fig. 3. Open evaluation analysis with Atlas.ti 6.2: learning dimensions, total number of associated quotations, and most cited emerging codes.

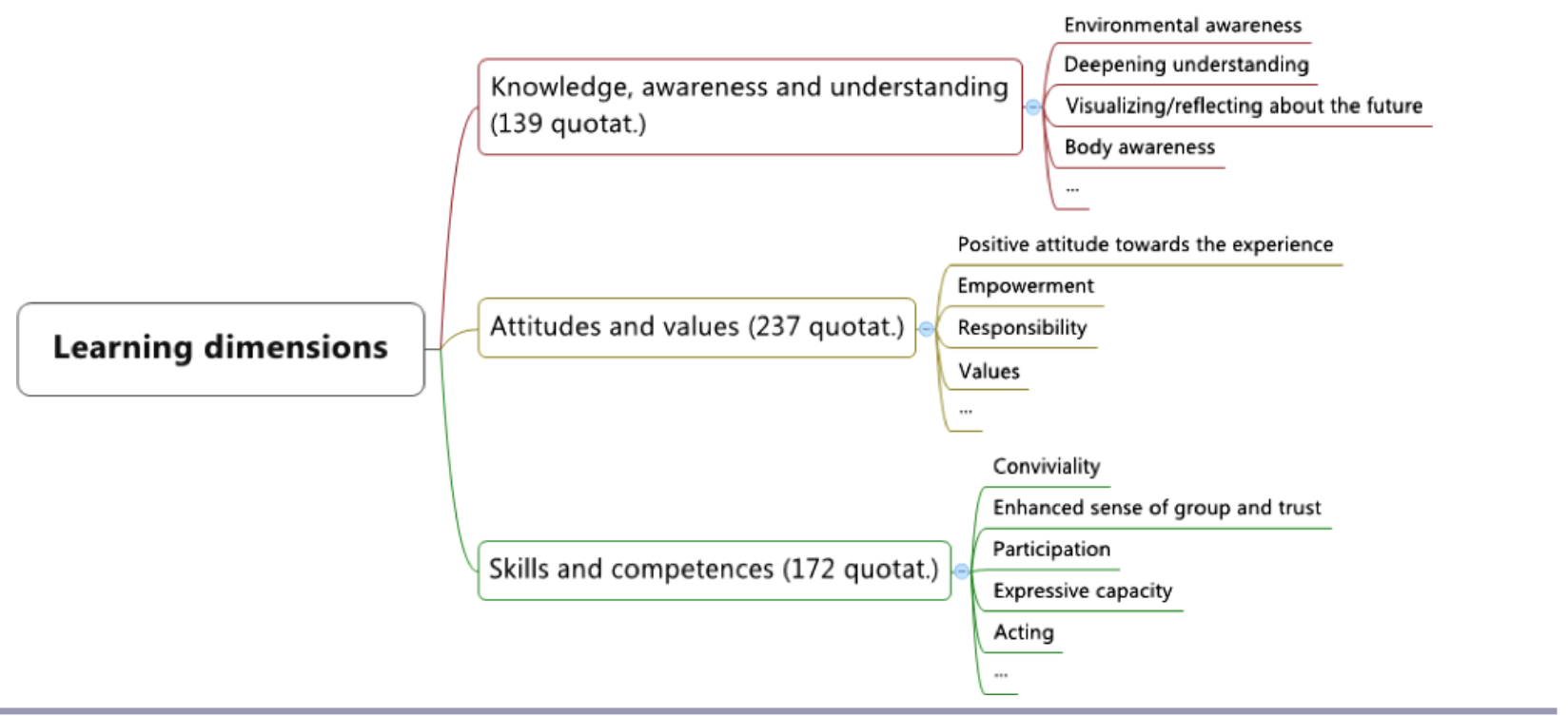

Through their oral (group G1) and performed (groups G2, G3) interventions, different proposals of action were identified. Most of these proposals implied (1) individual actions in the short term, both proactive and reactive, which could be partially explained by the immediacy of the theatrical setting and guidelines; and (2) collective actions, some of them relating to the medium- or longterm, such as starting up a community organic garden at the highschool (G1), generating a process of community traditional knowledge recovery $(\mathrm{G} 1)$, or involving the whole community (children, youth, adults, elderly) in coordinated actions to take care of their environment (G3).

\section{Process outcomes: participants' learning experiences}

In this subsection we review results from the qualitative evaluation and the pre- and postworkshop questionnaires, supported by researchers' observations, to explore the less tangible but fundamental learning outcomes facilitated by the theatrical experience. The qualitative analysis of the final open questionnaire and the reflection cards helped identify three broad learning dimensions: (1) awareness, knowledge, and understanding; (2) attitudes and values; and (3) skills and competences (see Fig. 3 ). We then triangulated such analysis with the results from the pre- and postworkshop questionnaires.

In general, participants often identified the theatrical workshop and the methodology applied as different ways of learning about their own social-ecological realities in a highly cooperative and playful mode. How we learn became a shared subject of participants' reflections, which emphasised specific features of the performative approach, such as being inspiring, allowing for different forms of expression, enhancing freedom, or learning outdoors. We introduce in the next subsections specific reflections and excerpts from the three analysis categories. Appendix 3 contains additional quotes that further illustrate each analysis dimension.
Awareness, knowledge, and understanding

Most of the participants' answers expressed that the workshop helped them better understand their community and the problems affecting the MAB Reserve. Such answers included topics and discussions addressed through the scenes and forum improvisations, such as forest depletion, agriculture and the use of genetically modified crops, environmental health, and the rise of social conflicts. Participants' reflections on learning were often associated with the possibility of imagining themselves in different and future situations, but also with increased awareness about these problems, their complex and interconnected dynamics, and the need to take care of them:

\section{[The workshop] helped me think about things like: how could my community be? How could young people be in different situations? I think the value of it lies in helping to become aware of what's happening in our community. (a participant from G3) \\ This workshop has a value in getting to know the consequences of our acts and how they are going to affect us in the future. The environment also needs care to be taken. (a participant from G1)}

Furthermore, such strengthened awareness also included a physical and relational component operating at a very personal level. In particular, some participants' statements also suggest becoming aware of themselves in relation to the group, of their body expressivity and of the capacity to communicate in other ways than the spoken word (see Appendix 3). This embodiment of scenes and narratives allowed for the emergence of different ways of knowing not only oriented to assimilate and process information, but also to connect oneself with the group and the body, our main sensorial means for understanding and relating to the outer world. Such a diversity of learning resources seemed to help reinforce attitudes and perceptions regarding sustainability challenges in the MAB Reserve. 
Attitudes and values

Similarly to the awareness manifested, participants' answers expressed their concerns about the future of their community and the MAB Reserve. However, beyond that, they also showed a sense of responsibility and ownership about their future:

[The workshop] helped me know that there can actually be other solutions to the problems we are facing and that we could help more our environment. (a participant from G1)

I've learnt from the futures activity that we all have the freedom to choose what we want to do and the kind of relationship that we want to have with our environment. (a participant from $\mathrm{G} 2$ )

Likewise, almost all participants identified specific actions of change and a number of them also formulated motives behind such actions, showing proactive attitudes (e.g., "it's time to... otherwise..." and "because of that, we should..."). Normative statements were also recurrent in such formulations (e.g., "we must..." and "we should not..."). Similarly, a number of statements reflected an appreciation for and empathy toward nature within the MAB Reserve. Many participants used plural pronouns (we, us), and moral judgements were commonly associated with feelings of appreciation, bonding, and empathy, as well as values such as tolerance, respect, and love:

We should not exploit our environment or feel like their masters...we should feel part of it. (a participant from G1)

[I understood] that we are all people and we can all understand...and that the environment is the most beautiful thing, it gives us life. (a participant from G1)

Comparing the pre- and postworkshop questionnaires, our analysis suggests that, with a few exceptions, these possible attitudes were reinforced, rather than significantly modified, as a result of the workshop (see Table A2.2 for further details). However, two items did show significant response changes among several groups: the motivation to do things for the community (Q6) and the importance of the role of the youth (Q8). Both items significantly increased in G2 and G3 (motivation), and in G1 and G2 (important role of the youth). In the cases in which Q6 and Q8 did not change significantly (G1 and G3, respectively), their mean values were already high before the workshop and remained high (value means over 4.14). This is of special relevance because such items correspond to two crucial dimensions of the workshop: the focus on motivations to act and on the activation of the youth.

\section{Social and expressive skills}

A number of answers indicated that the theatrical activities helped develop and practice different social and expressive skills. These include acting, reflecting, sharing ideas, and taking joint decisions. Conviviality was specially highlighted by a significant number of answers as the main value of the workshop. Relaxed participation and cooperative group work provided the opportunity to better know each other, share personal experiences, engage in fruitful dialogues, and organize themselves so as to create theatrical scenes together:

... At the beginning, I was shy and afraid of being mocked, but it was not that way: we all participated and there were no bad words from other classmates. I loved it, we could all give our opinions and they were all respected. (a participant from G1)

I realized that if we manage to agree, we can build together shapes with our bodies and [integrate] the abilities of each one of us. (a participant from G3)

Participants' answers also suggested AT's potential to create spaces of empathic communication and mutual understanding. This in turn had a positive effect on the actual configuration of the group and the perception of participants toward the others, e.g., through recognition of other participants' qualities:

The main value of the workshop was communication, respect, tolerance, and mutual understanding. (a participant from G2)

There were classmates with which I did not get on well. However, during the workshop we managed to become friends in just three days, when I thought it would take much longer. (a participant from G1)

A number of participants mentioned that they experienced changes in their social skills as a consequence of their participation, like improving their self-confidence and abilities to communicate and interact in a more tolerant and cooperative mode with the group, better expressing themselves, or losing the fear of sharing their opinions and ideas (see Appendix 3). However, analyzing deeper changes in self-perceptions may require longer time spans and research designs, as results from the Likert scales suggest. According to the pre- and postworkshop questionnaires, participants perceived that creativity did not change significantly in any of the groups and their immediate perceptions of their communicative capacities significantly increased only in G1. These tempered data seem coherent when contextualized with the other evaluation tools, because Likert scales addressed changes in absolute perceptions, which may be stronger, whereas statements from the feedback questionnaire were comparative or relative, and the open evaluation allowed participants to express nuances.

\section{Feedback questionnaire}

Results from the feedback questionnaire carried out four months later showed strong agreement among participants that the workshop goals had been accomplished (see Table 2). Participants in the three groups specially acknowledged the workshops' capacity to foster conviviality among the group and enhance their expressive skills. Such experience also especially helped them reflect on the current social-ecological dilemmas (in G2 and G3) and share their views and experiences within the group (in G1).

\section{DISCUSSION}

I learnt today that each one of us can create the future. (a participant from G2)

\section{Facilitating participation for futures thinking: key} methodological features of AT

Our results allowed us identify at least three interconnected methodological features of AT that when properly integrated into the design of performative scenarios have the potential to generate significant added value in participatory futures thinking. In particular, such added value is emphasised whenever the process (1) follows a participant-centered design and implementation, (2) supports playfulness and mutual cooperation, and (3) encourages embodied systems experimentation. 


\section{Participant-centered}

Participants' personal experiences and perceptions of the community and its futures were a starting point in our process to engage with participants' imaginations. By entering into participants' worlds, theatrical exercises were able to represent not only social-ecological interactions within the community, but also participants' meanings, emotions, and motives behind them, which were expressed organically through embodied dramatic action. Such situated actions, very importantly, presented under their own terms, provided relevant narratives to participants, enhancing their interest in and connection to the stories. However, this relevance also contributed to create future scenes in which "real" people with specific roles, responsibilities, motives, and intentions were also portrayed. Thus, there is a potential to contribute to salient visions, which in turn are key in sustainability transformations, because to be relevant, visions "ought to matter to the people for whom they imagine a desirable future" (Wiek and Iwaniec 2014:502).

\section{Playful and cooperative}

Because some difficulties in participating fluently were observed at the beginning, time was allocated in every session to group games to activate participants, lose inhibitions, create a sense of mutual support, and enhance concentration. These games were key to connect with participants, create a relaxed atmosphere, and foster affective connections and responses. Although some students had more difficulties than others, positive changes in participation could be generally observed even during a single session. Games also allowed for a progressive adaptation to the theatrical methodology and constituted a way to approach the initial shyness, lack of self-confidence, and sometimes, apathy.

During the theatrical exercises, the performative approach showed its potential to stimulate participants' engagement and social skills through its playful, cooperative, and active character. On the one hand, the creation of scenes and sketches in small groups, in which everyone played a role, extended participation beyond those who frequently used to lead or dominate the discussions. Fiction and the urgency of action inherent to improvisations (i.e., everyone on stage needs to do something) helped students participate in nonthreatening ways. Indeed, playful, fictional, and dramatic action can provide the distance to "reflect more securely upon issues which have significant effects upon our lives" (Winston and Tandy 1998, as cited in McNaughton 2004). On the other hand, the creation of scenes required a great deal of imagination and a committed group working together on sharing experiences, collectively reflecting ideas, distributing tasks, creating and negotiating scenes, and performing together, among other tasks. Such a creative atmosphere may, in turn, inspire participants' visions of the future. Furthermore, by acknowledging different positions and negotiating and integrating them in collective creation, the theatrical exercises represented a way of mapping out and managing diversity, a critical step toward shared visions of future (van Kerkhof and Lebel 2006).

\section{Embodied systems experimentation}

Drama exists in physical action. By acting and reflecting upon action, the theatrical approach stimulated active contributions to the topics addressed, which were not only rationalized or analyzed as abstract concepts but also felt and sensed. The representation of concrete characters and situations helped ground the discussions into known realities, whereas felt experience while playing provided bridges to more abstract concepts. For instance, while discussing the scenario cards, participants often had difficulties in identifying scenario-related values (the concept of value was difficult per se). Performing scenes helped visualize such values and facilitated in some cases the identification and understanding of more specific social-ecological values, e.g., intergenerational justice and social equity. In this fashion, the dynamic quality of theater allowed the reflections to move back and forth among different dimensions, e.g., from the concrete enacted situations to abstract associated values and beliefs, from the local to the global, and from personal to societal. By contrasting and connecting different dimensions, these movements could contribute to reinforce the systemic approach and coherence of the visions and futures created, acknowledging and addressing inherent tensions. Such embodied experimenting with systems knowledge constituted the basis for an alternative mode of experiential learning that opened up new creative spaces, where the range of possibilities was pushed by the imagination of the participants.

\section{Learning implications of AT's features and relevance within educational contexts}

Results from our experience suggest that, at their best, the above features can facilitate the integration of different learning dimensions (awareness and understanding, attitudes and values, social and cooperative skills) in a highly engaging and participatory space. Integrating different learning dimensions is crucial in those educational programs that want to stimulate students' critical engagement into action for sustainability, beyond learning about sustainability as a concept (Krasny et al. 2009, Frisk and Larson 2011).

Although workshop interventions showed that participants had multiple pieces of relevant knowledge about the MAB socialecological context, such knowledge often lacked a critical framework connecting it to their own experiences, values, and visions, so as to ultimately link their insights to particular actions. In this regard, the main value of our proposal may not lie in the generation of new knowledge, because contents were mainly defined by participants, but above all, in its socialization and the articulation of meanings and purposes around it. This resulted in a strengthened social-ecological awareness, which included as well relational and embodied dimensions.

Such awareness was also fostered through theater's experiential character, which helped participants experience their community and the MAB Reserve as a complex system. In line with other experiences (Dieleman and Huising 2006, Booth-Sweeney and Meadows 2010), games and performing played an essential role in approaching systems' complexity, firstly by providing accessible metaphors and lively experiences to participants and secondly through debriefing moments in which they could critically process, reflect upon, and articulate those insights. In this way, participants could potentially feel that complexity beyond cognitive analysis.

Performing the different roles allowed participants to give life to their own stories and actors. Such systems' embodiment and felt experiences emphasized their emotional connections to both imagined and existing realities, and also helped expose their feelings about the uncertainties related to the MAB Reserve future. In this way, the workshop provided a space to share and 
acknowledge the vital affective dimension involved in thinking about the future (Dator 2002, Hicks and Holden 2007). As workshop and evaluation data suggest, the affective and emotional approach helped reinforce appreciative and emphatic attitudes toward nature. This capacity for empathy, for a sort of "we feeling," is a key element in sustainability learning processes that expect to transform values and visions and provoke changes in the ways we relate to the world (Orr 1992, De Haan 2006). If MAB Reserves are also aimed at supporting a sense of place and an emotional connection with nature (Schultz and Lundhom 2010), then providing supportive contexts and spaces for participants' disclosure, where young people can start sharing desires and concerns and processing the worldviews behind them rather than just processing more information, seems essential. Indeed, people's worldviews and mental models are seen as underlying variables ultimately affecting a system's socialecological resilience (Berkes and Folke 1998, Schultz and Lundhom 2010).

However, approaching and experiencing the future may be of little value if no connection to agency is made (Hicks and Holden 2007). In this regard, the workshop also explored participants' motivations to act and unfolded social and cooperative skills needed for collective action. Forum theater provided a rehearsal arena where different skills and conditions enabling community action could be scrutinized. Through their participation in fictional contexts, students used and tested real knowledge and real skills (McNaughton 2004), which are important in the building of strategic competences (i.e., identifying and mobilizing resources, building cooperative networks, acknowledging uncertainties) highlighted in sustainability education approaches (De Haan 2006, Wiek et al. 2011). Evaluation results also showed that participants' motivations to act and their perception of the important role of the youth significantly increased after the workshop. Addressing strategic capacities and fostering participants' motivation is crucial because feeling disempowered could deepen young people's disillusionment about the future (Eckersley 1999).

In this regard, there is a pending opportunity for the integration of young people into mutual learning processes currently going on in MAB Reserves. As different studies show (Schultz and Lundhom 2010, Reed and Massie 2013), young people normally remain aside of such processes within MAB Reserves, being involved mostly in unidirectional educational programs. The theatrical approach could, thus, provide an engaging way of connecting and communicating the visions of young people to bridging organizations and other stakeholders already engaged in mutual learning processes around the MAB Reserves' management. Furthermore, if the creative process were directly fueled by MAB's research and monitoring data, it could also represent a way of connecting the students with current real practices and innovations. This would surely afford a communicative role but also could provide participants with hope, because MAB Reserves are devised as highly innovative social learning spaces; therefore, opportunities for action should be greater than in other places.

\section{Limitations}

Implementation limitations were mostly because of having extended the original group size to the whole school grade. Although participants' availability and access were ensured, some activities required more time, hence tightening the agenda. At the same time, the number of facilitators could not be readapted to the new group size because of a limited budget, and facilitation was sometimes in need of more human resources. As a result, less time was available for debriefing, and emotional disclosure within the group was sometimes harder to achieve. We also observed other implementation factors constraining discussion, which could easily be improved in other situations, such as (1) the sessions' particular timing, which made the most intense discussion coincide with the end of the sessions, when many participants were already tired or hungry; and (2) the space, sometimes too noisy ( $\mathrm{G} 2$ and $\mathrm{G} 3$, indoors) or too hot ( $\mathrm{G} 1$, outdoors). In addition, the theatrical methodology implies a progressive adaptation of participants to the theatrical language and the creation of an atmosphere conducive to emotional disclosure. This is quite time consuming and an inherent limitation of the method, but once such momentum is created, it represents one of the method's main potentials. The necessary adaptation to the theatrical methodology and the generation of a comfortable space constitute, therefore, a trade-off, which can be overcome by taking into account appropriate time requirements in the sessions' design phase.

On the other hand, the interconnected nature of social-ecological problems makes the rehearsal of potential actions and solutions particularly challenging. In forum performances, participants rehearse immediate actions that can potentially change the course of events in a given situation. This brings up to the question of how such action rehearsals can approach the complexity of unsustainability problems, in which local contexts are the result of multiple interactions among actors and social-ecological dynamics at multiple levels. In this regard, the proposal could greatly benefit from bringing other stakeholders into stage and making stronger connections between young people and community articulation processes, as well as from dedicating more time to deepening and refining initial action proposals emerging from the forum. This said, it is also important to bear in mind that these theatrical techniques were not created to find a solution, but rather to activate people in the search for solutions (Boal 2002).

Regarding the efficiency of the approach in provoking changes, although observational data and answers to the open evaluation and the return questionnaire strongly suggested changes in participants' expressive skills, their self-perception of their expressivity remained low for $\mathrm{G} 2$ and $\mathrm{G} 3$ in the Likert scales. Similarly, the Likert scales also suggested for these two groups an enhanced perception of the youth as change actors, while at the same time, their perceived self-efficacy (actual capacity to act) remained low. These results indicate a mismatch in the younger two groups, which the workshop could not address in its short implementation. Deeper changes in self-perceptions probably require longer time frames and processes, as well as further exploration of participants' agency and its connection to broader articulation processes.

\section{CONCLUSION: WHO OWNS THE FUTURE? HOW CAN I BE PART OF IT?}

In this paper we have explored the potential and the limitations of AT for futures thinking in sustainability education. Through an empirical experience in a MAB Reserve, we have illustrated how performative scenario making can help connect visions about 
the future with meaning and embodied action among young people. Individual desires and concerns were linked to community challenges, fostering participants' awareness about their role to become an active part of their own futures.

Through our dramatized scenes, possible and desired futures were explored, but most importantly, they were explored together with the actions needed to achieve them. In this way we moved away from the conventional understanding of scenario making by addressing the question of "what role can I play in this future?" In this sort of dramatized back-casting, special emphasis was put on generating critical reflectivity about the complexity of community challenges while not becoming so overwhelmed by them as to inhibit action. Focusing on understanding motives and fostering motivation allowed developing concrete proposals and linking them with their own contexts of action and available resources at hand. The participant-centered, playful, and embodied character of the performative approach provided a significant added value to futures thinking from a systems perspective. Learning about the complexity of social-ecological systems not only as something out there, but also as an emotional, personal, and lived experience was crucial to stimulate reflections on action.

However, this process was not without limitations, mostly related to the time framework and the resources available to implement the design. Deeper changes in self-perceptions and participants' agency require longer processes and their articulation within broader community action. Moreover, the interconnected and dynamic nature of sustainability problems and solutions requires rehearsals of action where multiple dimensions and action scales can be linked. This is a challenge for AT, which tends to focus on immediate changes by given actors. All in all, although more time and work are required to further enhance personal and collective competences to deal with the future and further test the robustness of our approach, our case provided a series of lessons, in the form of basic requirements and practical insights, that could be integrated in the future if AT is applied in other educational contexts and MAB Reserves.

In the face of the mounting environmental challenges and overwhelming doom predictions about global environmental change, performative learning methods may open a space for constructing a future of hope. Integrating the arts in such a space can foster open communicative processes where conventional linear thinking and constrained visions of futures can be overcome. If sustainability learning is about transforming and improving the quality of our social-ecological interactions, then people need to be given the opportunities to imagine alternative futures and become actively engaged with them. Methodological proposals such as the one proposed in this action research could not only help free such imagined and alternative future visions, but also activate young people to start cocreating and becoming owners of their futures.

Responses to this article can be read online at: http://www.ecologyandsociety.org/issues/responses. $\mathrm{php} / 8317$

\section{Acknowledgments:}

This research was supported by a grant (FIDGR-2011) from the Catalan Government. It was also possible thanks to the project Diseño y Evaluación de Herramientas Lúdicas de Aprendizaje Socioambiental para estudiantes de Secundaria en Territorios Montañosos Tropicales Bajo Régimen de Reserva de la Biosfera, supported by the Sectorial Research Fund for Education from the Mexican Government (SEP/SEB-CONACYT, 2013-2014). We would like to thank Enrique Garcia-Barrios (ECOSUR) for his support and trust during fieldwork. We are also thankful to Louis Lemkow for his feedback and Viki Reyes and Laura Calvet for their support with the statistical analysis. We would like to specially acknowledge and thank all the students from the community of Los Ángeles (La Sepultura) who participated in our workshops, as well as their teachers and school director for being open to our proposal.

\section{LITERATURE CITED}

Barth, M., and G. Michelsen. 2013. Learning for change: an educational contribution to sustainability science. Sustainability Science 8(1):103-119. http://dx.doi.org/10.1007/s11625-012-0181-5

Berkes, F., and C. Folke. 1998. Linking social and ecological systems for resilience and sustainability. Pages 1-25 in F. Berkes, C. Folke, and J. Colding, editors. Linking social and ecological systems: management practices and social mechanisms for building resilience. Cambridge University Press, Cambridge, UK.

Boal, A. 1992. Games for actors and non-actors. Routledge, New York, New York, USA.

Boal, A. 2009. Teatro del oprimido. Alba Editorial, Barcelona, Spain.

Booth-Sweeney, L., and D. Meadows. 2010. The systems thinking playbook: exercises to stretch and build learning and systems thinking capabilities. Chelsea Green Publishing, White River Junction, Vermont, USA.

Conrad, D. 2004. Exploring risky youth experiences: popular theatre as a participatory, performative research method. International Journal of Qualitative Methods 3(1):12-25.

Curtis, D. J. 2009. Creating inspiration: the role of the arts in creating empathy for ecological restoration. Ecological Management \& Restoration 10(3):174-184. http://dx.doi. org/10.1111/j.1442-8903.2009.00487.x

Curtis, D. J., N. Reid, and G. Ballard. 2012. Communicating ecology through art : what scientists think. Ecology and Society 17(2):3. http://dx.doi.org/10.5751/ES-04670-170203

Dator, J. 2002. Advancing futures: futures studies in higher education. Praeger, Westport, Connecticut, USA.

De Haan, G. 2006. The BLK '21' programme in Germany: a 'Gestaltungskompetenz'-based model for education for sustainable development. Environmental Education Research 12 (1):19-32. http://dx.doi.org/10.1080/13504620500526362

Dieleman, H., and D. Huisingh. 2006. Games by which to learn and teach about sustainable development: exploring the relevance of games and experiential learning for sustainability. Journal of Cleaner Production 14(9-11):837-847. http://dx.doi.org/10.1016/ j.jclepro.2005.11.031 
Eckersley, R. 1999. Dreams and expectations: young people's expected and preferred futures and their significance for education. Futures 31(1):73-90. http://dx.doi.org/10.1016/ s0016-3287(98)00111-6

Flowers, A. A., J. P. Carroll, G. T. Green, and L. R. Larson. 2015. Using art to assess environmental education outcomes. Environmental Education Research 21(6):846-864. http://dx.doi. org/10.1080/13504622.2014.959473

Frisk, E., and K. L. Larson. 2011. Educating for sustainability: competencies \& practices for transformative action introduction. Journal of Sustainability Education 2(March):1-20.

García Barrios, L. E., J. N. Toral, R. T. Vázquez, and J. L. Méndez. 2006. Diseño participativo y establecimiento de sistemas sustentables de producción agro-silvo-pastoril para la conservación de suelo, agua y especies arbóreas, en la zona de amortiguamiento de la Reserva de la Biosfera "La Sepultura.” Propuesta de Proyecto para financiamiento del Fondo Mix to Chiapas y Conacyt, Ciudad de México, Mexico.

Greenwood, J. 2011. Aesthetic learning, and learning through the aesthetic. Pages 47-52 in S. Schonmann, editor. Key concepts in theatreldrama education. Sense Publishers, Rotterdam, Netherlands.

Head, S. 2010. Forward theatre: futures studies in drama. Thesis. University of Queensland, Australia. [online] URL: http://www. metafuture.org/sabinathesiscla.pdf

Head, S. 2011. Forward theatre: an introduction. Journal of Futures Studies 16(2):17-34.

Head, S. 2012. Forward theatre and causal layered analysis. Journal of Futures Studies 17(1):41-56.

Heras, M., and J. D. Tàbara. 2014. Let's play transformations! Performative methods for sustainability. Sustainability Science 9:379-398. http://dx.doi.org/10.1007/s11625-014-0245-9

Hicks, D. 1996. Retrieving the dream: how students envision their preferable futures. Futures 28(8):741-749. http://dx.doi. org/10.1016/0016-3287(96)00032-8

Hicks, D., and C. Holden. 2007. Remembering the future: what do children think? Environmental Education Research 13 (4):501-512. http://dx.doi.org/10.1080/13504620701581596

Inwood, H. J. 2008. At a crossroads: situating place-based art education. Canadian Journal of Environmental Education 13 (1):29-41.

Kagan, S. 2008. Sustainability: a new frontier for the arts and cultures. Vas Verlag Fur Akademisch, Frankfurt, Germany.

Kolb, D. A. 1984. Experiential learning: experience as the source of learning and development. Prentice-Hall, Upper Saddle River, New Jersey, USA.

Krasny, M. E., K. G. Tidball, and N. Sriskandarajah. 2009. Education and resilience: social and situated learning among university and secondary students. Ecology and Society 14(2):38. [online] URL: http://www.ecologyandsociety.org/vol14/iss2/ $\underline{\operatorname{art} 38 /}$

Lehtonen, A. 2012. Future thinking and learning in improvisation and a collaborative devised theatre project within primary school students. Procedia-Social and Behavioral Sciences 45:104-113. http://dx.doi.org/10.1016/j.sbspro.2012.06.547

McNaughton, M. J., 2004. Educational drama in the teaching of education for sustainability. Environmental Education Research 10 (2):139-155. http://dx.doi.org/10.1080/13504620242000198140

Meadows, D. 2001. Dancing with systems. Donella Meadows Institute, Norwich, Vermont, USA. [online] URL: http:// donellameadows.org/archives/dancing-with-systems/

Meadows, D. H., D. L. Meadows, and J. Randers. 1992. Beyond the limits to growth: global collapse or a sustainable future. Earthscan, London, UK.

Meza, A. 2015.¿Qué motiva a l@sniñ@s rurales de la CARTREBISE, Chiapas, a conservar y a degradar su patrimonio natural? Tesis de Maestría en Ciencias en Recursos Naturales y Desarrollo Rural, El Colegio de la Frontera Sur, San Cristóbal de Las Casas, Chiapas, Mexico.

Miller, R. 2006. Futures studies, scenarios, and the "possibilityspace" approach. Pages 93-105 in Think scenarios, rethink education. OECD, Paris, France. http://dx.doi.org/10.1787/9789264023642-7-en

Miller, R. 2007. Futures literacy: a hybrid strategic scenario method. Futures 39(4):341-362. http://dx.doi.org/10.1016/j. futures.2006.12.001

Muñoz J. J., and M. A. Sahagún-Padilla. 2011. Análisis cualitativo asistido por ordenador con ATLAS.ti. Pages 299-363 in C. Izquierdo and A. Perinat, editors. Investigar en psicología de la educación. nuevas perspectivas conceptuales y metodológicas. Amentia, Barcelona, Spain.

Nicholson, H. 2005. Applied drama. Theatre and performance practices. Palgrave-Macmillan, Basingstoke, UK.

Orr, D. 1992. Ecological literacy: education and the transition to a postmodern world. State University of New York Press, Albany, New York, USA.

Pahl-Wostl, C., M. Craps, A. Dewulf, E. Mostert, D. Tabara, and T. Taillieu. 2007. Social learning and water resources management. Ecology and Society 12(2):5. [online] URL: http:// www.ecologyandsociety.org/vol12/iss2/art5/

Reed, M. G., and M. M. M. Massie. 2013. Embracing ecological learning and social learning: UNESCO biosphere reserves as exemplars of changing conservation practices. Conservation \& Society 11(4):391-405. http://dx.doi.org/10.4103/0972-4923.125755

Robinson, J. 2003. Future subjunctive: backcasting as social learning. Futures 35(8):839-856. http://dx.doi.org/10.1016/ s0016-3287(03)00039-9

Sanfiorenzo-Barnhard, C., L. García-Barrios, E. MeléndezAckerman, and R. Trujillo-Vázquez. 2009. Woody cover and local farmers' perceptions of active pasturelands in La Sepultura biosphere reserve buffer zone, Mexico. Mountain Research and Development 29(4):320-327. http://dx.doi.org/10.1659/mrd.00013

Scheffer, M., J. Bascompte, T. K. Bjordam, S. R. Carpenter, L. B. Clarke, C. Folke, P. Marquet, N. Mazzeo, M. Meerhoff, O. Sala, and F. R. Westley. 2015. Dual thinking for scientists. Ecology and Society 20(2):3. http://dx.doi.org/10.5751/ES-07434-200203 
Schultz, L., and C. Lundholm. 2010. Learning for resilience? Exploring learning opportunities in biosphere reserves. Environmental Education Research 16(5-6):645-663. http://dx.doi. org/10.1080/13504622.2010.505442

Selman, P., C. Carter, A. Lawrence, and C. Morgan 2010. Reconnecting with a neglected river through imaginative engagement. Ecology and Society 15(3):18. [online] URL: http:// www.ecologyandsociety.org/vol15/iss3/art18/

Sipos, Y., B. Battisti, and K. Grimm. 2008. Achieving transformative sustainability learning: engaging head, hands and heart. International Journal of Sustainability in Higher Education 9(1):68-86. http://dx.doi.org/10.1108/14676370810842193

Sloman, A. 2012. Using participatory theatre in international community development. Community Development Journal 47 (1):42-57. http://dx.doi.org/10.1093/cdj/bsq059

Speelman, E. N., L. E. García-Barrios, J. C. J. Groot, and P. Tittonell. 2014. Gaming for smallholder participation in the design of more sustainable agricultural landscapes. Agricultural Systems 126:62-75. http://dx.doi.org/10.1016/j.agsy.2013.09.002

Sprent, P., and N. C. Smeeton, editors. 2001. Applied nonparametric statistical methods. Chapman \& Hall/CRC, Boca Raton, Florida, USA.

Sterling, S. 2003. Whole systems thinking as a basis for paradigm change in education: exploration in the context of sustainability. Dissertation. University of Bath, Bath, UK.

Tàbara, J. D. 2013. Social learning to cope with global environmental change and unsustainability. Pages 253-265 in S. Lockie, D. A. Sonnenfeld, and D. R. Fisher, editors. The Routledge international handbook of social and environmental change. Routledge, London, UK. http://dx.doi.org/10.4324/9780203814550. $\underline{\operatorname{ch} 21}$

Tàbara, J. D., and I. Chabay. 2013. Coupling human information and knowledge systems with social-ecological systems change: reframing research, education, and policy for sustainability. Environmental Science and Policy 28:71-81. http://dx.doi. org/10.1016/j.envsci.2012.11.005

Tilbury, D., and D. Wortman. 2004. Engaging people in sustainability. IUCN, Cambridge, UK. [online] URL: http:// www.unece.org/env/esd/information/Publications $\% 20 I U C N /$ engaging $\%$ 20people.pdf

Trujillo Vázquez, R. J. 2010. Viabilidad ecológica y social del establecimiento de módulos silvo-pastoriles en el ejido los ángeles zona de amortiguamiento de la Reserva de la Biósfera la sepultura, Chiapas, México. Tesis Programa Oficial de Posgrado en Agroecología, Universidad Internacional de Andalucía (UNIA), Seville, Spain.

UNESCO. 2007.Teaching and learning for a sustainable future. UNESCO, Paris, France. [online] URL: http:/www.unesco.org/ education/tlsf/

UNESCO. 2014. Biosphere reserves - learning sites for sustainable development. UNESCO, Paris, France. http://www.unesco.org/ new/en/natural-sciences/environment/ecological-sciences/biospherereserves/
Van Erven, E. 2000. Community theatre. Routledge, New York, New York, USA. http://dx.doi.org/10.4324/9780203452431

van Kerkhoff, L., and L. Lebel. 2006. Linking knowledge and action for sustainable development. Annual Review of Environment and Resources 31:445-477. http://dx.doi.org/10.1146/ annurev.energy.31.102405.170850

Waters, S., H. Monks, J. Ayres, and S. Thomson. 2012. The use of Theatre in Education (TIE): a review of the evidence. Prepared by the Child Health Promotion Research Centre and Edith Cowan University. Constable Care Child Safety Foundation, Perth, Australia.

Wayman, S. 2009. Futures thinking, the ability to envision scenarios of a more desirable future. Pages 94-98 in A. Stibbe, editor. The handbook of sustainable literacy. Skills for a changing world. Green Books, Cambridge, UK.

Wiek, A., and D. Iwaniec. 2014. Quality criteria for visions and visioning in sustainability science. Sustainability Science 9 (4):497-512 http://dx.doi.org/10.1007/s11625-013-0208-6

Wiek, A., L. Withycombe, and C. L. Redman. 2011. Key competencies in sustainability: a reference framework for academic program development. Sustainability Science 6 (2):203-218. http://dx.doi.org/10.1007/s11625-011-0132-6 
APPENDIX 1 Workshop Structure: sessions, specific aims, guiding questions, other in-puts and tools.

\begin{tabular}{|c|c|c|c|c|}
\hline Session & Specific aims & Guiding questions/ Guidelines & Other inputs & Tools \\
\hline Transversal & $\begin{array}{l}\text { To foster cooperative } \\
\text { work and } \\
\text { participants' } \\
\text { communication skills } \\
\text { Introduction to the } \\
\text { theatrical language }\end{array}$ & - & - & $\begin{array}{l}\text { Theatrical games and group activities designed } \\
\text { to warm up and foster: } \\
\text { - } \quad \text { Physical awareness } \\
\text { - } \quad \text { Sense activation } \\
\text { - } \quad \text { Self and group awareness } \\
\text { - } \quad \text { Communication and cooperation }\end{array}$ \\
\hline $\begin{array}{c}\text { Session 1: } \\
\text { Picturing the } \\
\text { community }\end{array}$ & $\begin{array}{l}\text { To generate a shared } \\
\text { picture of the } \\
\text { community, its main } \\
\text { actors and social- } \\
\text { ecological } \\
\text { interactions }\end{array}$ & $\begin{array}{l}\text { What is your image of the } \\
\text { community? } \\
\text { What is your image of the youth } \\
\text { in your community? }\end{array}$ & $\begin{array}{l}\text { Reflection cards: } \\
\text { - What are the main elements that } \\
\text { characterize the community? } \\
\text { - Who are the main actors in the } \\
\text { community? } \\
\text { - How are their relationships? } \\
\text { - What do they do for a living? } \\
\text { - How are young people in the community? } \\
\text { - What do they do? }\end{array}$ & $\begin{array}{l}\text { Image theatre: } \\
\text { - The image of the community } \\
\text { - The image of the youth } \\
\text { Debriefing: } \\
\text { - What do you see in the image? (Different } \\
\quad \text { levels of observation) } \\
\text { - What kinds of relations do you identify? } \\
\text { - How does it make you feel? } \\
\text { - Would you add or change something? } \\
\text { - How would you like the image to be? } \\
\text { - Where are you in such images? }\end{array}$ \\
\hline $\begin{array}{l}\text { Session 2: } \\
\text { Visioning } \\
\text { futures }\end{array}$ & $\begin{array}{l}\text { To connect present } \\
\text { trends with plausible } \\
\text { futures } \\
\text { To foster visions of } \\
\text { future } \\
\text { To compare different } \\
\text { futures and identify }\end{array}$ & $\begin{array}{l}\text { How would the future of the } \\
\text { Reserve look like in } 20 \text { years if...? } \\
\text { (land-use strategy) }\end{array}$ & $\begin{array}{l}\text { Participants' land-use strategies resulted } \\
\text { from the previous environmental education } \\
\text { process : } \\
-\quad \text { Conservation } \\
-\quad \text { Intensification } \\
-\quad \text { Diversification } \\
\text { Discussion cards: How is your future scenario? } \\
\text { 1. Main economic activities }\end{array}$ & $\begin{array}{l}\text { Discussion groups } \\
\text { Image Theatre: the fluid image of the future } \\
\text { Debriefing: } \\
\text { - What characters do you see in scene? How do } \\
\text { - } \quad \text { Whey interact? } \\
\text { - What desirable aspects do you see? And what }\end{array}$ \\
\hline
\end{tabular}




\begin{tabular}{|c|c|c|c|c|}
\hline & desirable pathways & $\begin{array}{l}\text { the Reserve to look like in } 20 \\
\text { years? }\end{array}$ & $\begin{array}{l}\text { 2. Main actors } \\
\text { 3. Ecosystem services provided by the } \\
\text { social-ecosystem } \\
\text { 4. Relationship of humans with nature } \\
\text { according to their management strategy } \\
\text { 5. Main challenges faced by people } \\
\text { 6. Values associated to the scenario }\end{array}$ & $\begin{array}{l}\quad \text { negative aspects? } \\
-\quad \text { Which future elements do you prefer? }\end{array}$ \\
\hline $\begin{array}{c}\text { Session 3: } \\
\text { Rehearsing } \\
\text { present } \\
\text { transformation } \\
\mathrm{s}\end{array}$ & $\begin{array}{l}\text { To reflect about } \\
\text { current socio- } \\
\text { ecological dilemmas } \\
\text { faced by the } \\
\text { community and } \\
\text { explore different } \\
\text { solutions }\end{array}$ & $\begin{array}{l}\text { Think individually of a/several } \\
\text { identified negative aspect/s from } \\
\text { the future that you currently see } \\
\text { in your community } \\
\text { Share a story with the group } \\
\text { about a day-to-day situation } \\
\text { related to that aspect/s in which } \\
\text { you are involved }\end{array}$ & $\begin{array}{l}\text { - Identified negative aspects from the } \\
\text { future } \\
\text { - Own experiences }\end{array}$ & $\begin{array}{l}\text { Forum theatre: } \\
\text { Sharing of personal stories in subgroups } \\
\text { Improvisational sketch creation based on shared } \\
\text { stories. } \\
\text { Representation to the group and discussions: } \\
\text { What have we seen in the scene? } \\
\text { Who are the characters? What are the problems } \\
\text { reflected? } \\
\text { Does this happen in your community? How? } \\
\text { What's been your personal experience of it? } \\
\text { What could be different in this scene? How could } \\
\text { that change the outcome? } \\
\text { Debriefing: } \\
\text { What kinds of actions were proposed? } \\
\text { Do they represent possible solutions? How? } \\
\text { Are they feasible in our community? } \\
\text { What trade-offs do they imply? } \\
\text { What would be our role? } \\
\text { How would we like to engage in? }\end{array}$ \\
\hline
\end{tabular}




\section{APPENDIX 2 EVALUATION TOOLS}

A2.1. Evaluation tools applied before, during and after the workshop: timing, sample size and questionnaire questions and items. $Q=$ question/item in the Likert scale.

Open evaluation -At the end of the workshop

$\mathrm{n}=71$

5 open-ended questions

Participants were asked to share their individual appreciations of the experience and their reflections about the performative process, around the following dimensions:

1. Their felt experience and perceived value of the workshop

2. What they learned about their social-ecological system

3. Contributions of the theatrical tool to dialogue

4. Best and worse workshop features

5. Intentions of change after the workshop

Individual reflection cards - At the end of session 1 and 2

$\mathrm{n}=131[\mathrm{G} 1=42, \mathrm{G} 2=58, \mathrm{G} 3=41]$

2 open-ended questions

Participants were asked to individually reflect about and share:

1. The activity or workshop moment they liked the most and why

2. Something they found out or learned that day

Perception and attitudes questionnaire - Before and after the workshop

$\mathrm{n}=73+$

Five-point Likert Scale, 11 items

Participants were asked to self-rate their perceptions and attitudes towards:

1. Their creativity and self-expression capacity (Q1 and Q2)

2. Their community and their environmental situation:

- Feeling of belonging to the community (Q3)

- Interest about their community (Q4)

- Willingness to leave the MAB (Q5)

- Perception of environmental degradation as a threat to the MAB (Q7)

- Concern about the environmental situation of the MAB (Q9)

3. Their motivation to act and their role as young people:

- Motivation to act (Q6)

- Perceived importance of the role of the youth (Q8)

- Perception of future possibilities for the youth at the MAB (Q10) 
- Perceived capacity of action as young people (Q11)

Return questionnaire - Four months after the workshop

$\mathrm{n}=56[\mathrm{G} 1=14, \mathrm{G} 2=26, \mathrm{G} 3=26]$ *

Five-point Likert Scale questionnaire, 8 items and 5 open questions

Participants were asked to indicate to what extent the workshop helped them:

1. Feel more connected to other school mates

2. Feel more self-confident

3. Reflect about their community and relevant actors

4. Vision different community futures

5. Identify positive and negative aspects in such futures

6. Identify social-ecological challenges

7. Explore proposals of action

8. Share personal experiences, views and attitudes

For items 4 to 7 participants were asked to provide specific examples.

† Sample sizes of data used here for analysis are slightly lower than the number of participants answering them, since not all participants completed both questionnaires.

‡ Researchers' access to the field during a high-school vacation period hindered access to participants from G1. 
A2.2. Summary of results and main insights from questionnaires completed before and after the workshops: Group 1, Group 2 and Group 3.

Group 1

\begin{tabular}{|c|c|c|c|c|c|c|c|c|}
\hline \multicolumn{9}{|c|}{$n=28$} \\
\hline$Q$ & $\begin{array}{l}\text { Mean } \\
B\end{array}$ & $\begin{array}{l}\text { Std. } \\
\text { Dev. B }\end{array}$ & Mean $A$ & $\begin{array}{l}\text { Std. } \\
\text { Dev. A }\end{array}$ & $\begin{array}{l}\text { Positive } \\
\text { difference }\end{array}$ & $\begin{array}{l}\text { Negative } \\
\text { difference }\end{array}$ & Tides & $\begin{array}{l}\text { Wilcoxon } \\
\text { Test }\end{array}$ \\
\hline Q1 & 4,107 & 0,629 & 4,179 & 0,723 & 9 & 5 & 14 & 0,401 \\
\hline Q2 & 3,464 & 1,036 & 4,143 & 0,705 & 11 & 1 & 16 & 0,003 \\
\hline Q3 & 4,500 & 0,638 & 4,214 & 0,686 & 4 & 11 & 13 & 0,064 \\
\hline Q4 & 4,357 & 0,780 & 4,500 & 0,923 & 11 & 7 & 10 & 0,347 \\
\hline Q5 & 2,857 & 1,433 & 2,607 & 1,449 & 8 & 8 & 12 & 0,624 \\
\hline Q6 & 4,321 & 0,723 & 4,357 & 0,678 & 7 & 7 & 14 & 0,931 \\
\hline Q7 & 3,786 & 1,449 & 3,964 & 1,401 & 8 & 8 & 12 & 0,747 \\
\hline Q8 & 3,821 & 1,278 & 4,250 & 0,928 & 11 & 5 & 12 & 0,086 \\
\hline Q9 & 4,643 & 0,488 & 4,321 & 0,772 & 4 & 10 & 14 & 0,091 \\
\hline Q10 & 4,429 & 0,879 & 4,536 & 0,637 & 8 & 7 & 13 & 0,798 \\
\hline Q11 & & & & & & & & \\
\hline
\end{tabular}

Group 2

\begin{tabular}{l|l|l|l|l|l|l|l|l}
\hline $\mathbf{n = 2 3}$ & $\begin{array}{l}\text { Mean } \\
B\end{array}$ & $\begin{array}{l}\text { St. Dev. } \\
\text { B }\end{array}$ & Mean A & $\begin{array}{l}\text { Std, } \\
\text { Dev, } A\end{array}$ & $\begin{array}{l}\text { Positive } \\
\text { difference }\end{array}$ & $\begin{array}{l}\text { Negative } \\
\text { difference }\end{array}$ & Tides & $\begin{array}{l}\text { Wilcoxon } \\
\text { Test }\end{array}$ \\
\hline$Q$ & $\mathbf{3 , 4 7 8}$ & 0,994 & $\mathbf{3 , 8 7 0}$ & 0,757 & 8 & 2 & 13 & $\mathbf{0 , 0 6 0}$ \\
\hline Q1 & 2,522 & 1,675 & 2,478 & 1,163 & 7 & 7 & 9 & 0,975 \\
\hline Q3 & 4,304 & 1,063 & 4,348 & 1,112 & 5 & 5 & 13 & 0,906 \\
\hline Q4 & 4,435 & 0,945 & 4,391 & 0,722 & 4 & 6 & 13 & 0,563 \\
\hline Q5 & 2,652 & 1,584 & 2,435 & 1,647 & 6 & 8 & 9 & 0,527 \\
\hline $\mathbf{Q 6}$ & $\mathbf{3 , 8 2 6}$ & 1,230 & $\mathbf{4 , 3 0 4}$ & 0,765 & 9 & 4 & 10 & $\mathbf{0 , 1 1 8}$ \\
\hline Q7 & 3,130 & 1,792 & 3,261 & 1,573 & 10 & 6 & 7 & 0,544 \\
\hline $\mathbf{Q 8}$ & $\mathbf{4 , 0 4 3}$ & 1,296 & $\mathbf{4 , 6 5 2}$ & 0,573 & 6 & 0 & 17 & $\mathbf{0 , 0 1 5}$ \\
\hline Q9 & 4,522 & 0,665 & 4,348 & 0,832 & 2 & 5 & 16 & 0,291 \\
\hline Q10 & 3,391 & 1,438 & 3,130 & 1,486 & 4 & 7 & 12 & 0,346 \\
\hline Q11 & 2,52 & 1,70 & 2,52 & 1,50 & 7 & 6 & 10 & 0,9236 \\
\hline
\end{tabular}

Group 3

\begin{tabular}{l|l|l|l|l|l|l|l|l}
\hline $\mathbf{n = 2 2}$ & $\begin{array}{l}\text { Mean } \\
B\end{array}$ & $\begin{array}{l}\text { St. Dev. } \\
B\end{array}$ & Mean A & $\begin{array}{l}\text { Std, } \\
\text { Dev, } A\end{array}$ & $\begin{array}{l}\text { Positive } \\
\text { difference }\end{array}$ & $\begin{array}{l}\text { Negative } \\
\text { difference }\end{array}$ & \begin{tabular}{l} 
Tides \\
\hline$Q$
\end{tabular} & $\begin{array}{l}\text { Wilcoxon } \\
\text { Test }\end{array}$ \\
\hline Q1 & 3,91 & 1,02 & 4,05 & 0,72 & 8 & 6 & 8 & 0,6094 \\
\hline Q2 & 2,77 & 1,31 & 2,64 & 1,09 & 8 & 10 & 4 & 0,6325 \\
\hline Q3 & 4,32 & 0,95 & 4,14 & 1,17 & 5 & 6 & 11 & 0,6614 \\
\hline Q4 & 4,14 & 0,89 & 4,18 & 0,96 & 7 & 6 & 9 & 0,8644 \\
\hline Q5 & 2,36 & 1,56 & 2,27 & 1,20 & 8 & 10 & 4 & 0,8562
\end{tabular}




\begin{tabular}{l|l|l|l|l|l|l|l|l} 
Q6 & $\mathbf{3 , 1 4}$ & 1,25 & $\mathbf{4 , 0 9}$ & 0,92 & 14 & 5 & 3 & $\mathbf{0 , 0 1 0 6}$ \\
\hline Q7 & 2,86 & 1,36 & 2,59 & 1,01 & 8 & 9 & 5 & 0,5077 \\
\hline Q8 & 4,32 & 0,99 & 4,14 & 1,17 & 6 & 7 & 9 & 0,6718 \\
\hline Q9 & 4,00 & 0,76 & 4,23 & 0,87 & 7 & 3 & 12 & 0,2449 \\
\hline Q10 & 2,86 & 1,28 & 2,55 & 1,37 & 7 & 10 & 5 & 0,4104 \\
\hline Q11 & $\mathbf{2 , 3 6}$ & 1,09 & $\mathbf{1 , 9 5}$ & 1,05 & 5 & 13 & 4 & $\mathbf{0 , 1 0 3}$ \\
\hline
\end{tabular}

\section{Main analysis insights:}

\section{Perceived creativity (Q1) and communicative skills (Q2)}

Participants' perceived creativity increased in G1 and G2 and remained the same in G3 (no significant changes however). Participants' perceptions of their communicative capacities significantly increased in G1, but remained low in G2 and G3.

\section{Motivation to act (Q6) and perceived importance of the role of the youth (Q8)}

The motivation to act (Q6) significantly increased in G2 and G3. In the youngest group, G3, the average value for motivation increased from 3,14 to 4,09, the highest increment in the questionnaire. The perceived importance of the role of the youth (Q8) significantly increased in G1 and G2. In G2, the perceived importance of the role of young people got the highest questionnaire score after the workshop, with an average value of 4,6.

In the cases in which Q6 and Q8 did not change significantly (G1 and G3 respectively), their mean values were already high before the workshop and remained high.

Perceptions and attitudes towards their community and the environment $(Q 3, Q 4, Q 5$, Q7, Q9)

Response changes showed high values and no significant variation for these items, except for the item on environmental concern (Q9), which slightly decreased in G1. Despite the decrease, Q9 kept a very high score in the three groups, with mean values over 4.

Perception of future possibilities for the youth at the MAB (Q10) and perceived capacity of action as young people (Q11)

No significant changes were found in participants' perception of future possibilities for the youth at the MAB (Q10), and no common pattern was followed in the three groups (while in G1 it remained very high; in G2 and G3, mean values remained around the middle position of the Likert scale). Participants' perceived capacity of action remained in a mean value (G2) or low (G3), showing a small but significant decrease in the youngest group, G3. 


\section{APPENDIX 3 \\ ADDITIONAL QUOTES FROM PARTICIPANTS' ANSWERS TO THE OPEN EVALUATION}

This appendix contains a further selection of quotes extracted from participants' answers to the open evaluation. These quotes have been organised according to the three broader learning categories of the qualitative analysis:

(i) Awareness, knowledge and understanding

(ii) Attitudes and values

(iii) Social skills and competences

\section{Awareness, knowledge and understanding}

Quotes about deepening awareness, understanding and making connections:

'Today I understood that there are trade-offs between everything'. A participant from $\mathrm{G} 2$

'I realised that cutting down the trees provokes landslides and not only that; it also provokes changes in temperatures'.

A participant from $G 2$

[Through the workshop I realised that] the environment needs care to be taken and how the ecosystem works.

A participant from $G 3$

Quotes about participants' embodied experience and body awareness:

'We were not just answering... we were acting and moving around'. A participant from $G 2$

'(I've learnt that) we don't need many things, we can just use our bodies to show others what we want to say'

A participant from $G 3$

'Through our bodies we can represent things and what we do in our community'. A participant from $G 2$ 
'I liked when we introduced ourselves and realised how we were feeling in that moment' A participant from $G 3$

\section{Attitudes and values}

Quotes about nature, their relation with it and their sense of responsibility:

'I learnt to appreciate what nature means in our day-to-day lives'.

A participant from $G 1$

'Today I found out that learning about nature is just beautiful'.

A participant from $G 2$

'The value of this workshop was to get to know my own responsibilities, things I hadn't thought about before... Now we know how to take care of them'.

A participant from $G 3$

'We can do something that is both good for the environment and for ourselves'. A participant from $G 2$

Quotes about theatre as way to learn:

[The workshop] has a lot of value because it teaches us different ways of thinking and creating'. A participant from $G 2$

'(Through theatre) we can represent what is really happening here to our natural resources'. A participant from $G 2$

'I liked this activity because I felt free'. A participant from $G 2$

\section{Social skills and competences}

Quotes about dialogue, co-creation and participation during the workshop: 
'I realized that even though we may not be close friends, we can get on well and [engage in a] dialogue together'.

A participant from $G 1$

'I loved the workshop because we could all equally participate'. A participant from $G 3$

'I could contribute with my time, my imagination and my ideas'.

A participant from $G 2$

'Participating I could better understand my mates'.

A participant from $G 3$

Quotes about interpersonal skills:

'[Now I feel that I'm] able to give a speech in front of the public without feeling nervous or anxiety because of talking'.

A participant from $G 1$

'I found out that I can share my opinions and I should lose the fear to do that.'

A participant from $G 2$

'[Now I'm going to be] nicer with my colleagues and give more my opinion about the topics we address'.

A participant from $G 1$ 